Portland State University

PDXScholar

$12-2012$

\title{
designBridge: Integrating Transportation into Service Learning Design/Build Projects
}

Juli Brode

University of Oregon

Nico Larco

University of Oregon

John Roswell

University of Oregon

Follow this and additional works at: https://pdxscholar.library.pdx.edu/trec_reports

Part of the Transportation Commons, Urban Studies Commons, and the Urban Studies and Planning Commons

Let us know how access to this document benefits you.

\section{Recommended Citation}

Brodi, Juli, Nico Larco and John Roswell. designBridge: Integrating Transportation into Service Learning Design/Build Projects. OTREC-ED-11-01. Portland, OR: Transportation Research and Education Center (TREC), 2010. https://doi.org/10.15760/trec.26

This Report is brought to you for free and open access. It has been accepted for inclusion in TREC Final Reports by an authorized administrator of PDXScholar. Please contact us if we can make this document more accessible: pdxscholar@pdx.edu. 

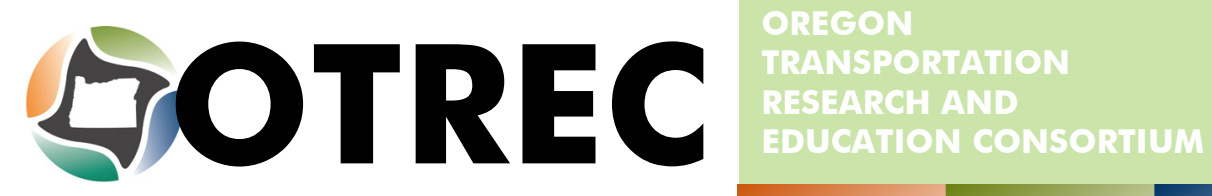

FINAL REPORT

\title{
designBridge: INTEGRATING TRANSPORTATION INTO SERVICE LEARNING DESIGN/BUILD PROJECTS
}

\author{
OTREC-ED-11-01 \\ December 2012
}





\title{
designBridge: INTEGRATING TRANSPORTATION INTO SERVICE LEARNING DESIGN/BUILD PROJECTS
}

\author{
FINAL REPORT \\ OTREC-ED-11-01 \\ by \\ Juli Brode \\ Nico Larco
}

University of Oregon

for

Oregon Transportation Research

and Education Consortium (OTREC)

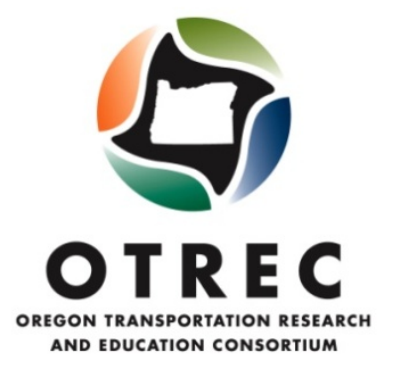

December 2012 



\begin{tabular}{|c|c|c|c|c|c|}
\hline \multicolumn{6}{|c|}{ Technical Report Documentation Page } \\
\hline $\begin{array}{l}\text { 1. Report No. } \\
\text { OTREC-ED-11-01 }\end{array}$ & \multicolumn{3}{|l|}{ 2. Government Accession No. } & \multicolumn{2}{|c|}{ 3. Recipient's Catalog No } \\
\hline \multirow{2}{*}{\multicolumn{4}{|c|}{$\begin{array}{l}\text { 4. Title and Subtitle } \\
\text { designBridge: Integrating Transportation into Service Learning Design/Build Projects }\end{array}$}} & \multicolumn{2}{|c|}{$\begin{array}{ll}\text { 5. } & \text { Report Date } \\
& \text { December } 2012\end{array}$} \\
\hline & & & & \multicolumn{2}{|c|}{ 6. Performing Organization Code } \\
\hline \multicolumn{4}{|l|}{$\begin{array}{l}\text { 7. Author(s) } \\
\text { Nico Larco } \\
\text { Juli Brode } \\
\end{array}$} & \multicolumn{2}{|c|}{ 8. Performing Organization Report No. } \\
\hline \multicolumn{4}{|c|}{ 9. Performing Organization Name and Address } & \multicolumn{2}{|c|}{ 10. Work Unit No. (TRAIS) } \\
\hline $\begin{array}{ll}\text { Juli Brode } & \text { Nico Larco } \\
\text { designBridge } & \text { Sustainable Cities Initiative } \\
\text { 219 Pacific Hall } & \text { 204 Pacific Hall } \\
\text { 1206 University of Oregon } & \text { 1206 University of Oregon } \\
\text { Eugene Oregon 97403-1206 } & \text { Eugene Oregon 97403-1206 } \\
\text { 12. Sponsoring Agency Name and Address } & \end{array}$ & \multicolumn{3}{|l|}{$\begin{array}{l}\text { Nico Larco } \\
\text { Sustainable Cities Initiative } \\
204 \text { Pacific Hall } \\
\text { 1206 University of Oregon } \\
\text { Eugene Oregon 97403-1206 }\end{array}$} & \multicolumn{2}{|c|}{ OTREC-2010-317 } \\
\hline \multicolumn{4}{|l|}{$\begin{array}{l}\text { 12. Sponsoring Agency Name and Address } \\
\text { Oregon Transportation Research } \\
\text { and Education Consortium (OTREC) } \\
\text { P.O. Box } 751 \\
\text { Portland, Oregon } 97207\end{array}$} & \multicolumn{2}{|c|}{$\begin{array}{l}\text { Final Report } \\
\text { October } 2009 \text { - March } 2011\end{array}$} \\
\hline \multicolumn{6}{|l|}{ 15. Supplementary Notes } \\
\hline \multicolumn{6}{|c|}{ 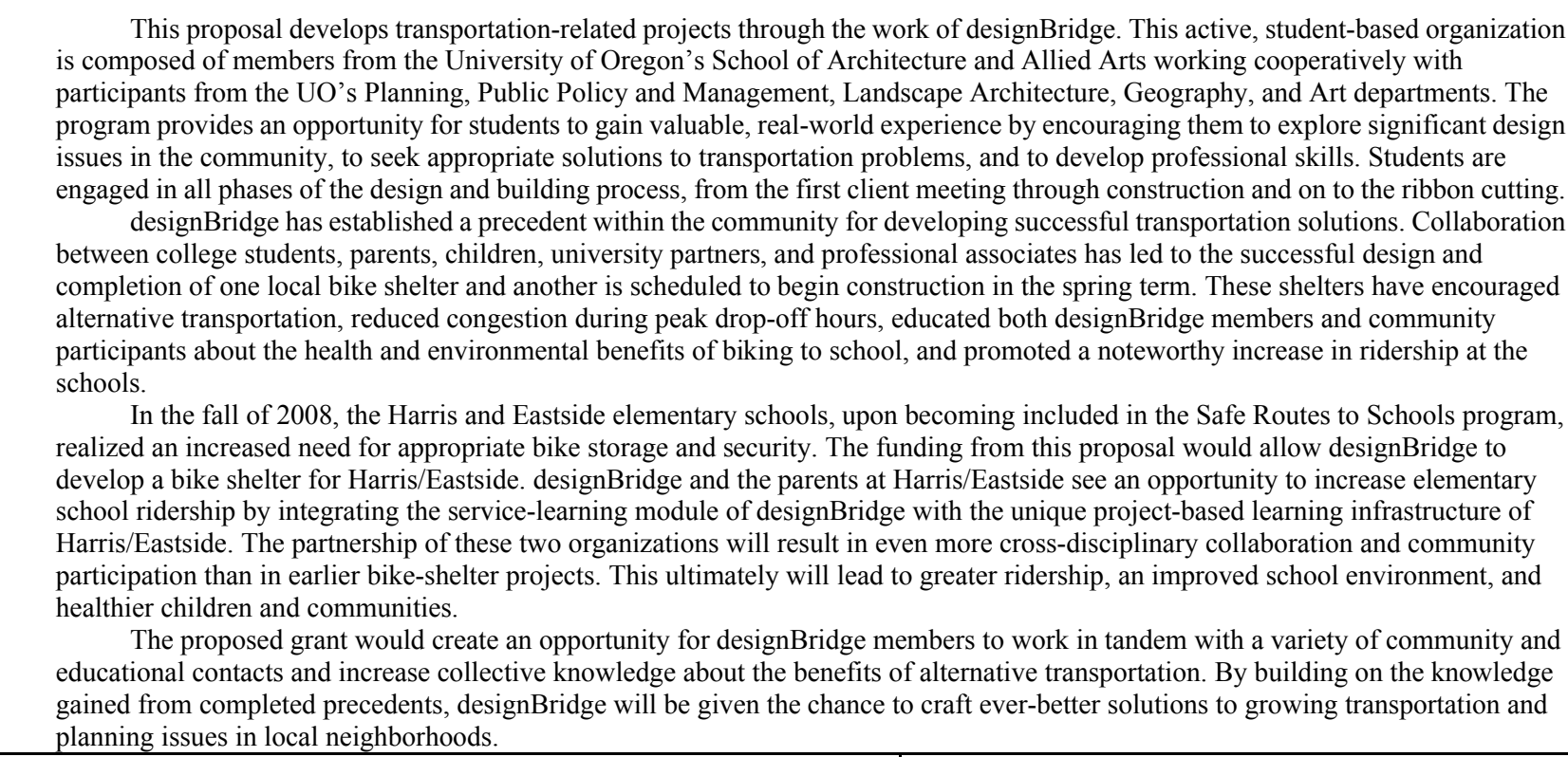 } \\
\hline \multicolumn{2}{|c|}{$\begin{array}{l}\text { 17. Key Words } \\
\text { healthy communities, alternate transportation, design/build, service } \\
\text { learning, applied learning, architecture education, Safe Routes to School, } \\
\text { bike shelters, pedestrian and biking routes, University of Oregon }\end{array}$} & \multicolumn{4}{|c|}{$\begin{array}{l}\text { 18. Distribution Statement } \\
\text { No restrictions. Copies available from OTREC: } \\
\text { www.otrec.us }\end{array}$} \\
\hline 19. Security Classification (of this report) & \multicolumn{2}{|c|}{$\begin{array}{l}\text { 20. Security Classification (of this page) } \\
\text { Unclassified }\end{array}$} & \multicolumn{2}{|c|}{$\begin{array}{l}\text { 21. No. of Pages } \\
32\end{array}$} & 22. Price \\
\hline
\end{tabular}




\section{ACKNOWLEDGEMENTS}

This project was funded by the Oregon Transportation Research and Education Consortium (OTREC) and designBridge, and the authors would like to thank OTREC and those students who dedicated their time to the transportation-related projects of the past year. This bike-shelter project was also made possible by the support of the Tom and Carol Williams Fund. From conception through design and implementation, this endeavor has been an effective synthesis of federal funding, university resources and community contributions.

We also would like to thank our clients, the Camas Ridge Community School students, staff, faculty, Principal Wally Bryant, and parent Mike McCann, for engaging designBridge and for working with us during the course of this project. We owe a thank you to many collaborators - Shane Rhodes and Safe Routes to School and the grant to SRTS that made the racks themselves possible; Vicki Bourcier, for her review of engineering calculations and details; the City of Eugene Permit Staff for guidance; Larry Massey with the 4J School District, whose attention to the schedule and patience throughout has been wonderful; John Rowell, who helped guide this project through designBridge coursework; Mark Young of Rowell-Brokaw Architects, who acted as a professional mentor for the project; and additional professional mentors and community volunteers, such as Toby Barwood of PIVOT Architecture, who have advised, assisted, and donated time and expertise during the course of the work.

The project would not have been possible were it not for the additional support of Adam Bonner of Hoffman Construction Co. who, though in the midst of his work on the construction of Matthew Knight Arena, had time for advice and review. When funds were lacking, he was eager to engage in work in his temporary community and sought to find other material vendors and contractors who were like-minded. We'd also like to recognize Jeremy Hart and Ming Surveying (help with site layout); Lee Weingardt and Farwest Steel (rebar); Kean Rager and Fortis Construction; Jay Patel and Knife River Precast Concrete (bending); Steve Parmeter and Star Rentals (buggy for concrete); Jim Lang and LaRusso Concrete (concrete finishing); Tim Hunter and W \& W Steel (shop drawings, steel and fabrication); David Copeland, Coping Trucking (steel shipping); Doug Peterson and Skyline Sheet Metal (sheet metal roofing); and Rick Allen, RB Allen Construction (general material delivery).

\section{DISCLAIMER}

The contents of this report reflect the views of the authors, who are solely responsible for the facts and the accuracy of the material and information presented herein. This document is disseminated under the sponsorship of the U.S. Department of Transportation University Transportation Centers Program and OTREC in the interest of information exchange. The U.S. Government and the sponsoring parties assume no liability for the contents or use thereof. The contents do not necessarily reflect the official views of the U.S. Government or OTREC. This report does not constitute a standard, specification, or regulation. 


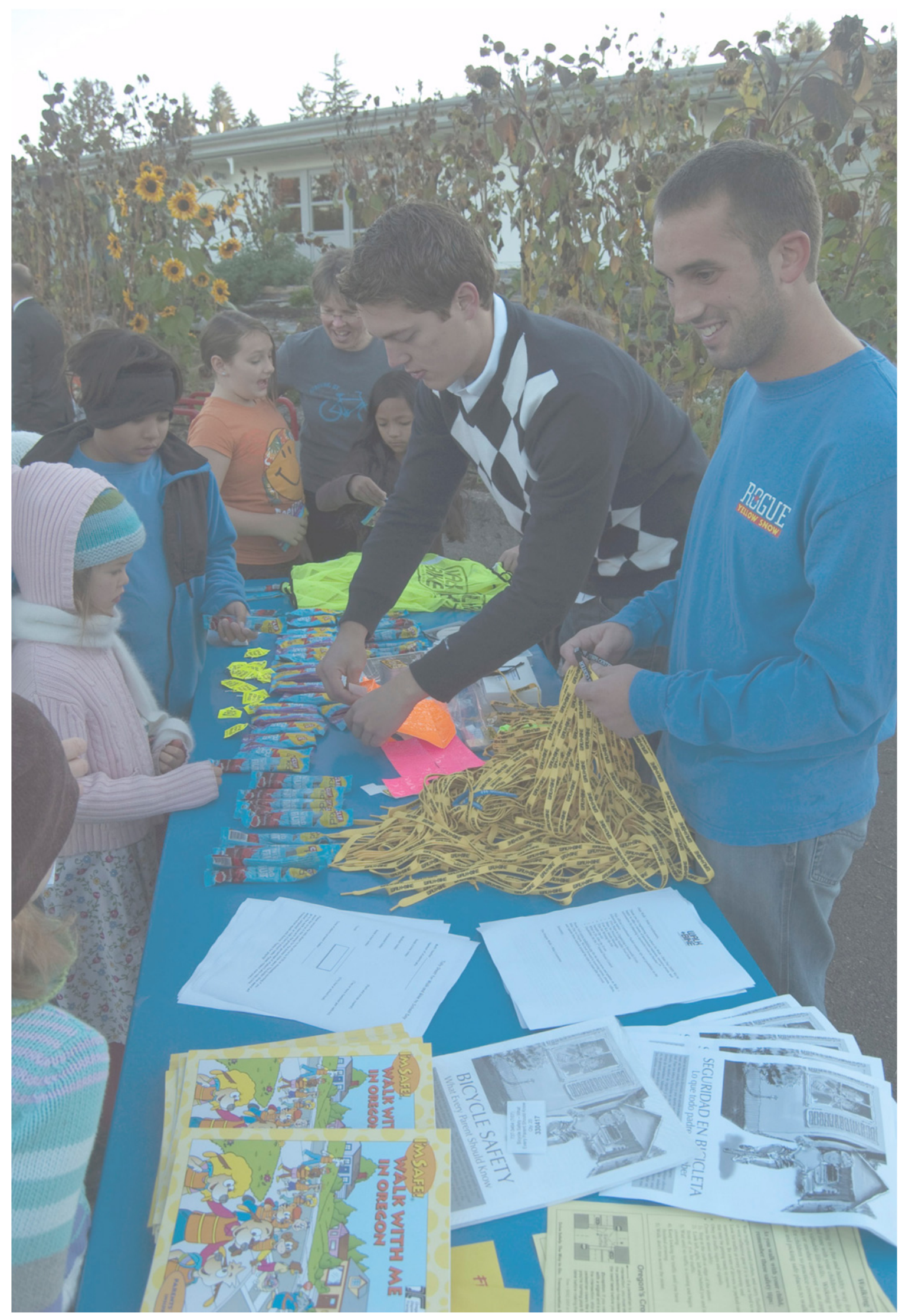

Alex Wilson and Henry Malmberg at National Walk and Bike to School Day, October 7, 2009. 


\section{designBridge: INTEGRATING TRANSPORTATION INTO SERVICE LEARNING DESIGN/BUILD PROJECTS}

\section{TABLE OF CONTENTS}

1.0 EXECUTIVE SUMMARY

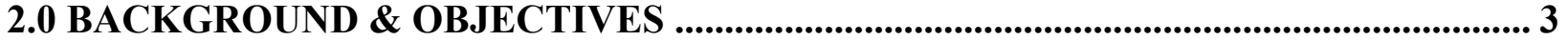

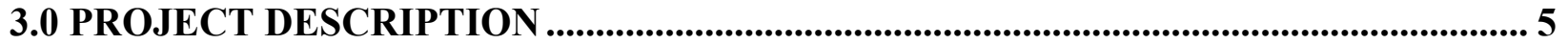

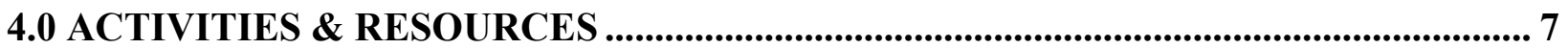

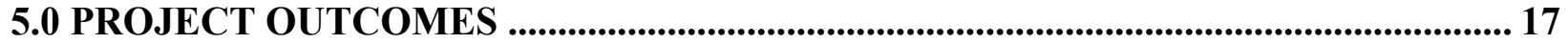

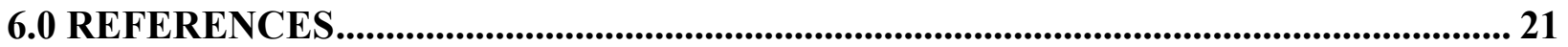

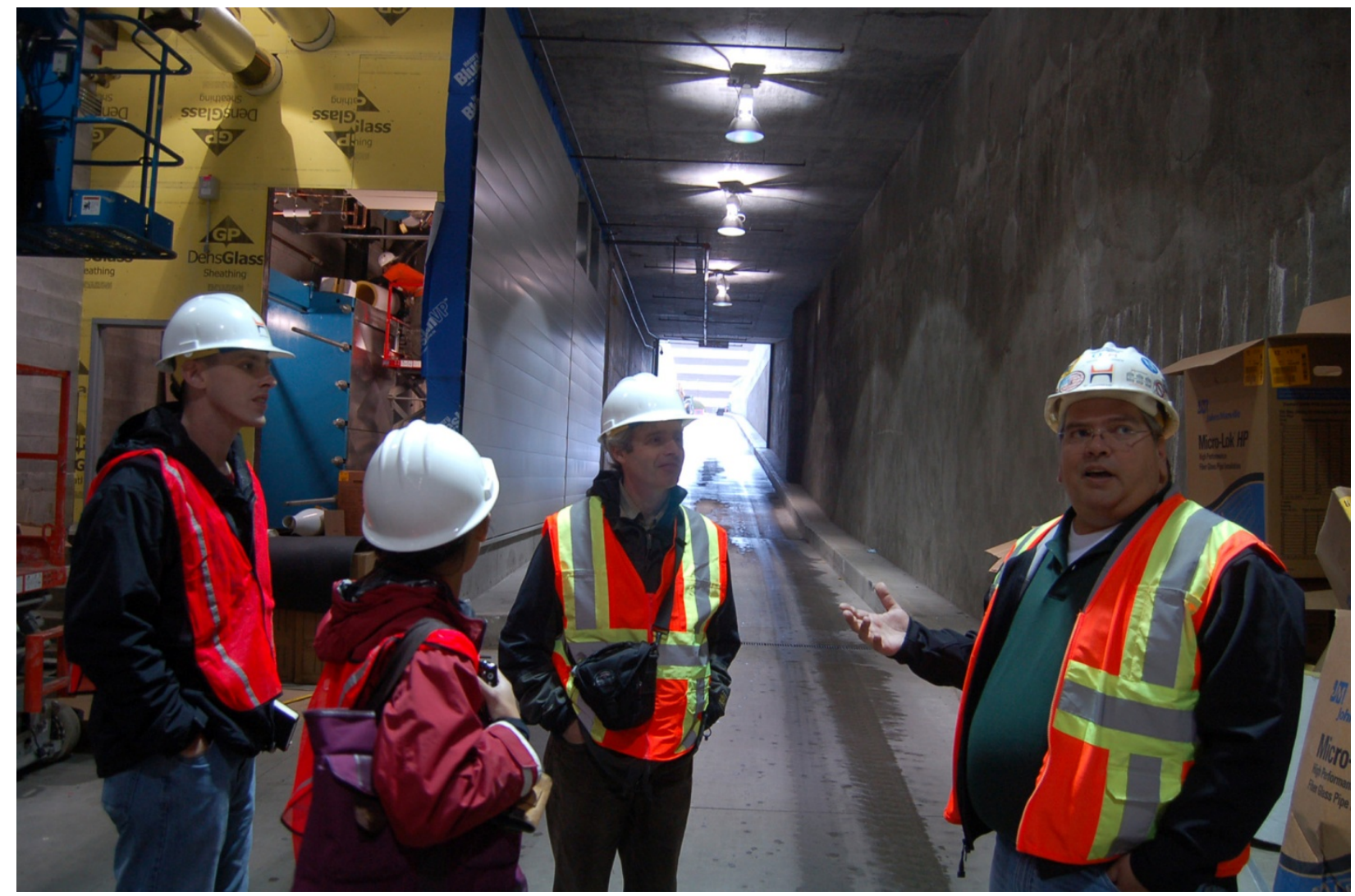

Adam Bonner, Site Supervisor for UO Arena/Hoffman Construction, leads MAK Court tour for designBridge Build/Tech class. Pictured here with Professor John Rowell and students. 


\subsection{EXECUTIVE SUMMARY}

This education project joins transportation-related issues with community-oriented projects through the multidisciplinary work of designBridge, a student-based organization focused on learning through identifying, planning, and carrying out design/build projects. The project directly supports OTREC's goal of increasing the number of university students engaged in the study of transportation-related issues, particularly in a multidisciplinary, experiential learning setting. By supporting this project, OTREC provides an opportunity to investigate and make visible, and more tangible, the idea of a healthy community. The project challenged Camas Ridge Community School students, parents, faculty and community members to examine bicycle transportation and multiple ways they might increase the number of students who ride to school.

The primary work encompassed the education and guidance of university students as they undertook the design and construction of a transportation shelter for Camas Ridge Community School in Eugene, OR. Camas Ridge is a recent combination of two elementary schools, and active parents and teachers, already familiar with Safe Routes to School (SRTS), quickly realized that they would need to address additional bike amenities and security for the larger student population. They were referred to designBridge by SRTS and Roosevelt Middle School (Bike Shelter, 2008-2009), as well as HIV Alliance (Outdoor Garden Room and Entry, 2008-2009).

The work directly addresses a number of transportation-related topics; by engaging various partners, and placing students in a place of central responsibility and decision-making, the topics could be explored from multiple perspectives. The process fosters a rich learning environment, an integrative design solution, a bridge connecting a university to its community, and a potential model for further small but critical education-fabrication projects. 


\subsection{BACKGROUND \& OBJECTIVES}

A project that seeks to engage university students in a transportation-related educational experience strongly supports USDOT and OTREC goals as identified in their respective strategic plans. Such projects present opportunities to focus university expertise on local issues, provide students with integrative pre-professional project experiences, and strengthen communities. Key goals identified with regard to this project are healthy communities, reduction of urban congestion, environmental stewardship, and the support of multimodal transportation opportunities.

Concerns regarding physical and environmental health are converging around transportation-related topics in many fields of study - health and wellness of adults and children, architecture and urban planning, and environmental studies, to name a few - and these disciplines document a mounting need to encourage and accommodate multimodal transportation. These are not only of professional interest, as they are global and civic issues as well.

According to the Physical Activity Guidelines for Americans, children and adolescents should participate in physical activity for at least 60 minutes each day, and studies show that children who exercise regularly are generally healthier, physically and mentally. Increasingly, children, as well as adults, are at risk for heart disease, high cholesterol, and Type 2 diabetes (Healthy Children Organization). The Centers for Disease Control and Prevention (CDC) states that approximately 17\% (about 12.5 million) of children and adolescents aged 2-19 are obese (Ogden and Carroll, 2010). Obesity among children has tripled since 1980 (CDC) and obese children are more likely to become obese adults. Low-income populations have a higher prevalence of childhood obesity (CDC), and in Lane County 6,002 families with children live below the federal poverty level (U.S. Census Bureau, 2000).

One obvious aspect is the decrease in regular, non-sports-related activity of individuals and families. The American Academy of Pediatrics has found that many children fall short of the recommended one hour of daily physical activity, and the academy urges regular activity on as many days as possible, even if it is broken up into 15-minute segments (Healthy Children Organization). The number of students who walk to school has decreased by as much as $40 \%$ (Killingsworth and Lamming, 2001), and researchers continue to draw direct connections between our health and physical activity and the design of our built environment (Loukaitou-Sideris, 2005). The CDC offers a number of recommendations for communities to address the childhood obesity epidemic, one of which is to focus on creating and maintaining safe neighborhoods for physical activity. The National Center for Safe Routes to School is building and providing resources that range from addressing school curriculum and increasing safe biking and walking routes to promoting both pedestrian and cycle options and ways to change school culture (SRTS). Carbon dioxide emissions are projected to continue to grow and the most effective way to reduce $\mathrm{CO}_{2}$ emissions is to reduce fossil fuel consumption (EPA). Encouraging children to incorporate walking and biking into their routines at an early age may affect air quality favorably in the future by directly reducing personal energy use.

designBridge is a multidisciplinary, student-based organization in the University of Oregon's School of Architecture and Allied Arts that engages in community-based design, planning and 
construction projects for clients who might otherwise not have access to professional services. The organization seeks those projects that present an active learning opportunity for students, an extension of the university's educational mission. Each spring the organization identifies community partners and projects that offer mutual benefits, suggesting that sustainability refers not only to the natural environment but also to community needs and well-being. This OTREC project supported the education of designBridge students during their design and building of a bicycle shelter for a local elementary school.

Many potential community partners are supportive of non-auto transportation. The City of Eugene is making increased efforts to plan for multimodal opportunities and to make decisions that strengthen bike travel across and within the city (City of Eugene). The 4J School District, which includes the Camas Ridge Community School, recognizes the need for school designs incorporating a safe and effective mixture of solutions for daily parking, car drop-offs, buses, and accommodations for walking and biking. Faced with budget challenges, the school district is not able to fund bike shelters, but is eager to support and facilitate these projects in other ways. The federal Safe Routes to School organization's goal is to accommodate and increase ridership of elementary students, teachers and parents. Eugene's strong, active SRTS chapter implements programs to increase child ridership and acts as a liaison to parents, cycling organizations and other community groups.

The National Council of Architectural Registration Boards (NCARB), which assesses architecture internship and licensing processes, and the National Architectural Accrediting Board (NAAB), which assesses architecture education, have determined that there are 17 components of the profession and practice in which students are routinely "deficient" (NCARB, 2008). Of the skills listed, NCARB identified12 that could be addressed through graduate and undergraduate curricula. By engaging the community in small projects with demonstrated need, designBridge students are immersed in a professional experience and gain basic skills and knowledge in a number of identified areas: Project Funding and Financing; Project Management; Legal and Ethical Issues Pertaining to Planning; Strategic Planning, Financial Management and Risk Management; Marketing and Communication; Human Resource Management; Entrepreneurship; and Mentoring and Teaching Others.

Through their participation in the Camas Ridge bike-shelter project, with a "real" client, students were given an opportunity to examine and advance both their written and visual communication skills. In school, they generally learn to relate to their peers; now, they were asked to converse and present to laypersons and community professionals. In the university setting, students often work on projects that are developed to an advanced schematic design phase, without knowing what comes next or how to develop a project further. By working on this community transportation shelter, students increased their knowledge of how materials are joined together and had to consider how these details would perform structurally and wear over time. Many aspects of a design education are explored conceptually and remain challenging to integrate.

Given the conditions outlined above, we proposed that multiple objectives (student education, design and fabrication of a needed school amenity, increased bike ridership) could be met successfully in a team-based learning environment that placed students in the realm of practice. 


\subsection{PROJECT DESCRIPTION}

In fall 2008, a parent active in his children's Safe Routes to School program approached designBridge with a request to consider addressing the bike-shelter needs of a local school. The school community faced the prospect of combining Harris Elementary and Eastside Elementary into one entity (Camas Ridge Community School) and the principal and teachers were keen to participate. Combining schools would alter the bike amenities required, and it also represented an opportunity to collaborate and establish a new identity for the merging Harris-Eastside groups. designBridge leaders perceived that the project would offer students a rich context for a valuable, applied learning process that addressed contemporary planning and transportation needs along with landscape, architectural and civic issues.

The project would build on a few years' experience - designBridge had completed some small, successful projects, including two bike shelters, and the organization had relationships with both the local Safe Routes to School (SRTS) program manager and the 4J School District architects. A 2008-2009 OTREC grant had supported one of the previous projects, and initial coursework that could lend support to a new bike-shelter project. The project was challenging in terms of funding, but some aspects were directly supported. Bike racks, as fabricated and finished products, were expensive butcould be provided by a grant awarded to SRTS; the principal had some discretionary funds that could be utilized for consultants and permitting; and the students' own hours of volunteer labor on design-build projects could offset a significant portion of market cost. Parents committed to raising the funds necessary for materials, which represented the bulk of the projected costs.

The general approach to a designBridge project includes a preliminary "project incubation" period, during which faculty advisors and student leaders meet with clients to discuss the broad strokes and main aspects of the project. This is followed by the three major phases: Pre-design and community outreach; design development; and construction and fabrication. Working as a team, students are central in the process. They have maximum opportunity to question, ask for guidance, and learn and apply. Most importantly, they stay focused on communication and decision-making. The students are encouraged to seek a professional mentor from the community, and the project team recruited Mark Young, an architect, parent and experienced cyclist. By combining strategies that included focusing on childhood educational activities, engaging professional partners, and assembling a multidisciplinary student team and faculty mentors, this small transportation project has been demanding and rewarding for designBridge in terms of its effectiveness in the community and student learning. 


\subsection{ACTIVITIES \& RESOURCES}

Chronologically, the academic calendar provided the framework in which the three phases occurred. Each of the three sequential, quarter-length courses is described below.

\section{Fall 2009: Pre-designBridge Seminar (3 credits) \\ Instructor: Juli Brode}

The course met twice weekly for a total of three hours a week; two graduate students and four undergraduate students spent approximately 278 hours on project work outside the classroom. Students chose two co-managers for their initial organizational structure and developed a team charter to establish ground rules. The initial focus was on a careful understanding and articulation of the problem and goals.

- Each student completed a self-assessment of their knowledge and skills in core competency areas prior to participation in the project.

- They researched those aspects of the design problem that relate to children's bicycling by familiarizing themselves with walking and biking issues, how those subjects are being explored elsewhere, and why alternate transportation is desirable, healthy and environmentally necessary. - Students found precedents from the U.S. and Europe of good solutions for access, shelters, racks, and general design ideas.

- They raised awareness of non-auto options and combined auto/bike options that people elsewhere are implementing, opening a discussion of how these decisions affect and hinge upon wider community planning.

Below left: Katie Martin talks to Camas Ridge students about the importance of walking and biking, and what form a bike shelter might assume at their school. One particularly imaginative drawing became an inspiration to the team, who mounted it on the studio wall during winter quarter.
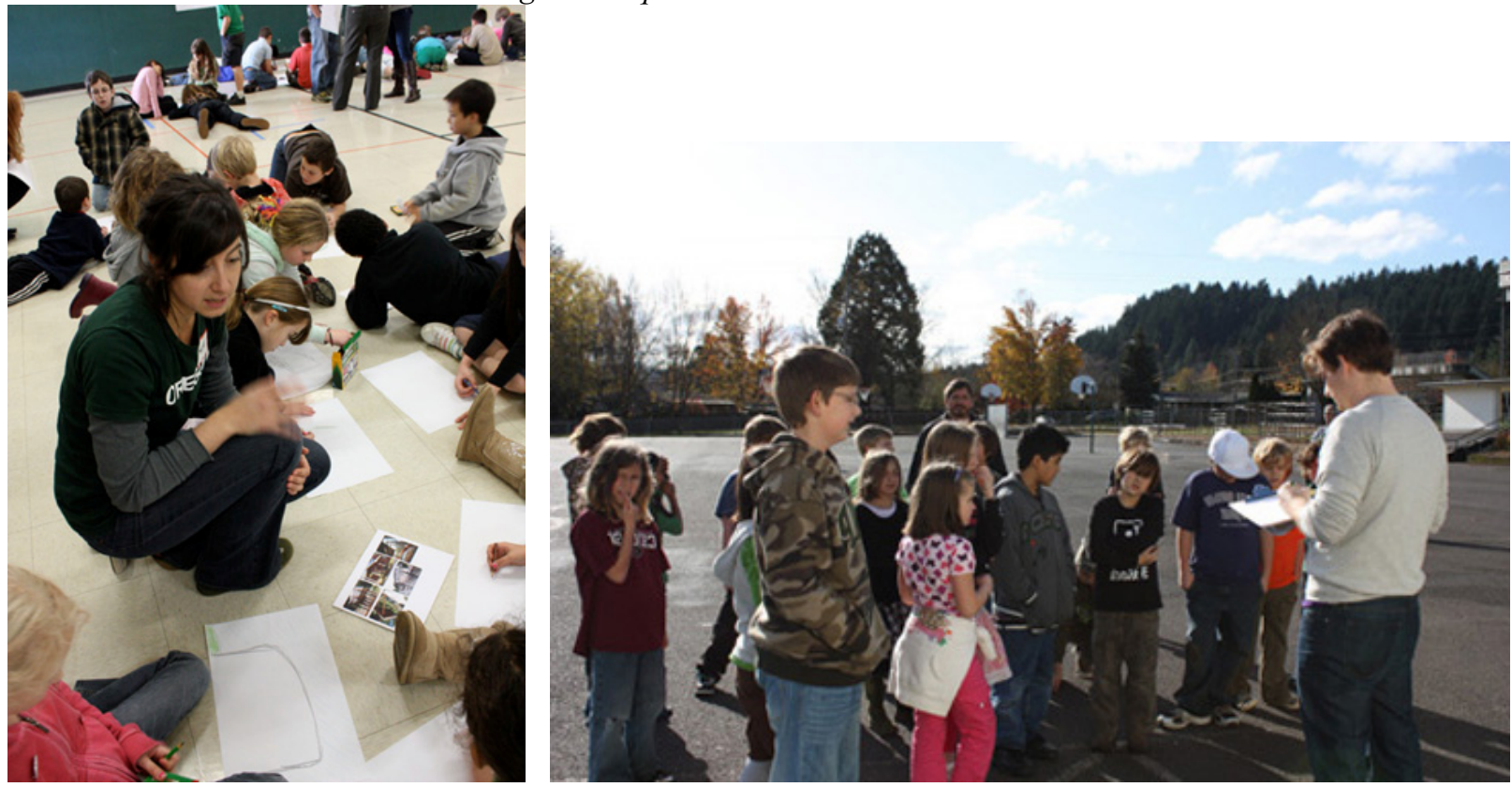

Above right: Client events were well attended by children, parents, teachers and staff. The interactions ranged from brainstorming and idea generation about the possible location of the bike shelter, such as this site walk with Nick Venezia, to more formal presentations of design schemes. 
- The team assessed the Camas Ridge school site and examined documents pertaining to the logistical requirements of the city planning department, the school district and SRTS.

- They liaised with 4J architects to understand any requirements they might have, reviewed planning and zoning codes and approval/permitting processes with them, and constructing a flowchart to guide their own approval process.

- They established the parameters of the design problem through additional site observation as well as precedent studies of shelters and small structures, and then developed preliminary schedules and budgets based on rough guesses.

- They created a shared resource binder and server file that allowed them to document and organize their work with a good degree of transparency and access.

- The education and inclusion of the facility's child users was critical, and with the teachers' help the designBridge students were able to connect with the elementary school children through activities and education surrounding walking and biking.

- They formally presented their design objectives, technical research, precedent studies and an initial scheme to a panel of faculty and professionals.

Fall quarter ended with an anonymous peer review and facilitated team discussions.

\section{Winter 2010: designBridge Studio (6 credits)}

Instructor: Juli Brode

The project team had developed clear objectives through pre-design activities, and two additional persons joined the team for the design studio. The studio met three times weekly for a total of 12 hours a week. This course became the major focus of three graduate and five undergraduate students; they worked on the project an average of 10 additional hours per week outside the classroom, yielding an approximate total of 720 additional volunteer hours.

- The quarter began with changes in team makeup and changes in roles and responsibilities.

- The design quarter began with formal studies of the general scheme developed in the fall quarter.

Think. Propose. Evaluate. (design, design, design)
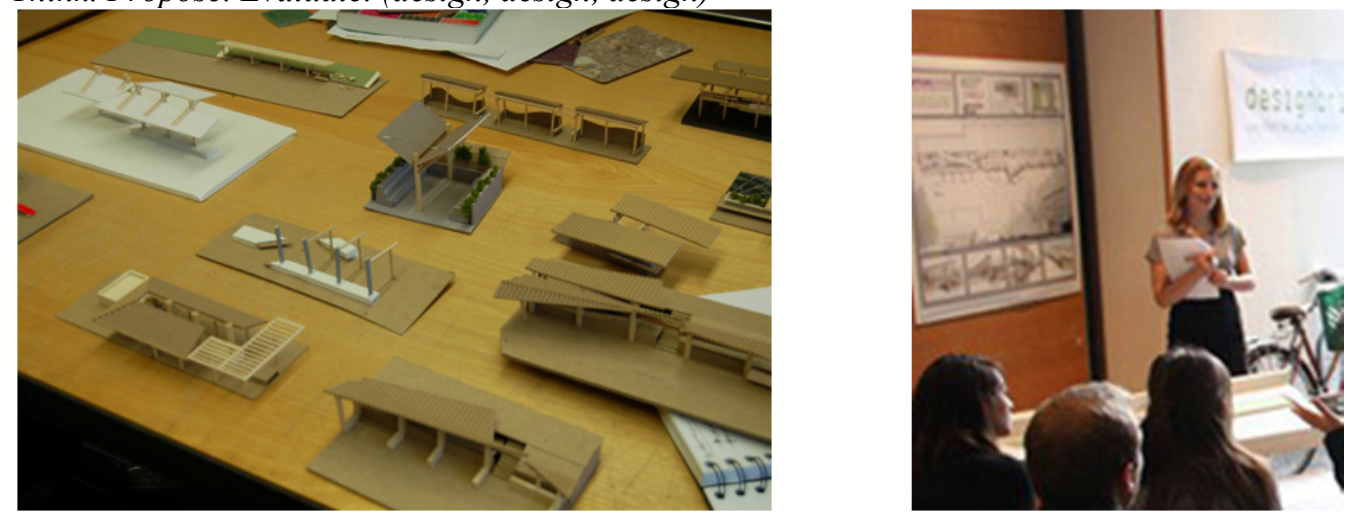

- The focus was on developing the design; refining the relationship to the adjacent slope; developing a structural system and material language; and crafting details and strategies for addressing shelter from sun and rain and accommodating rainwater.

- Teams of two completed "The Mule," a fabrication exercise using power tools and wood joinery methods designed to increase shop skills and collaborative fabrication work. 

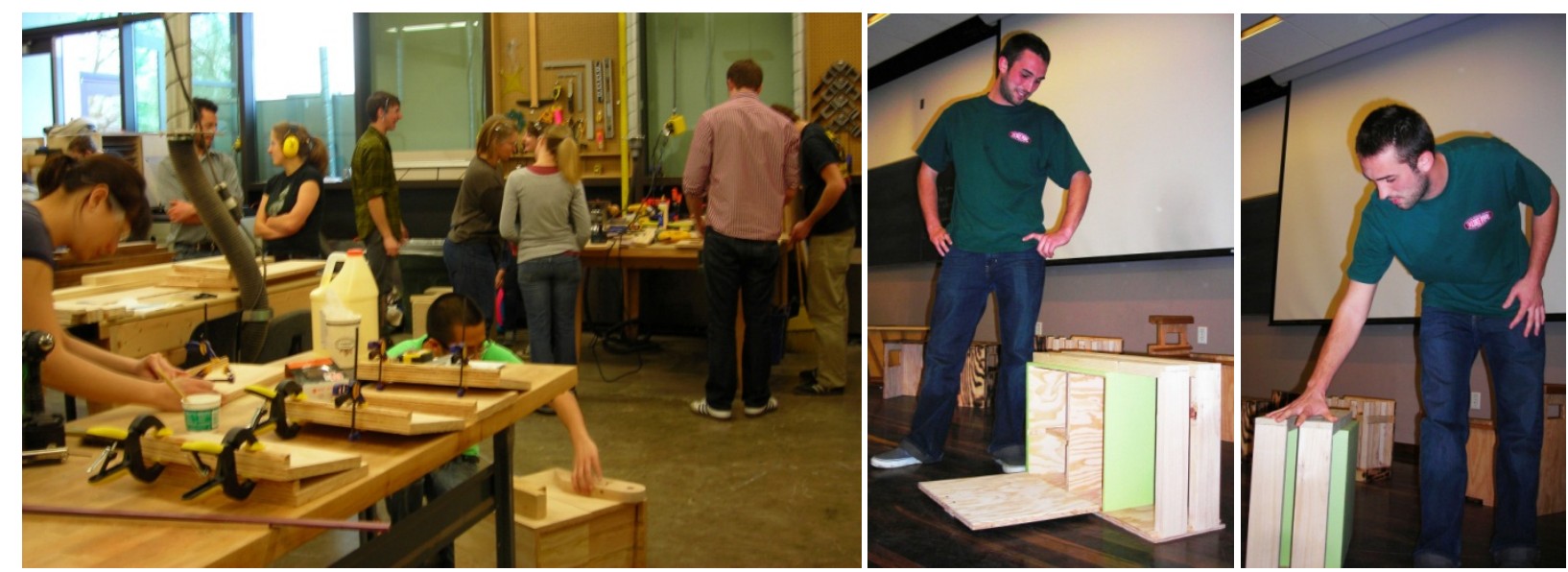

Working on The Mule: teams discuss and fabricate in the shop. Henry Malmberg demonstrates.

The mules were meant to seat two and to carry tools/drawings/equipment. Dimensions and materials were limited.

- A number of venues, ranging from discussions with consultants to informal reviews, gave different students occasions to present the project and ask questions of professionals.

- During a pre-design field trip, students had met Adam Bonner (Hoffman Construction) and he agreed to meet regularly regarding costs, budgeting and construction scheduling.

- Juli guided teams toward "build readiness."

-The students met regularly with a professional mentor, and a local engineer agreed to review their calculations and sketches.

-The project required a permit, necessitating a full set of permit documents.

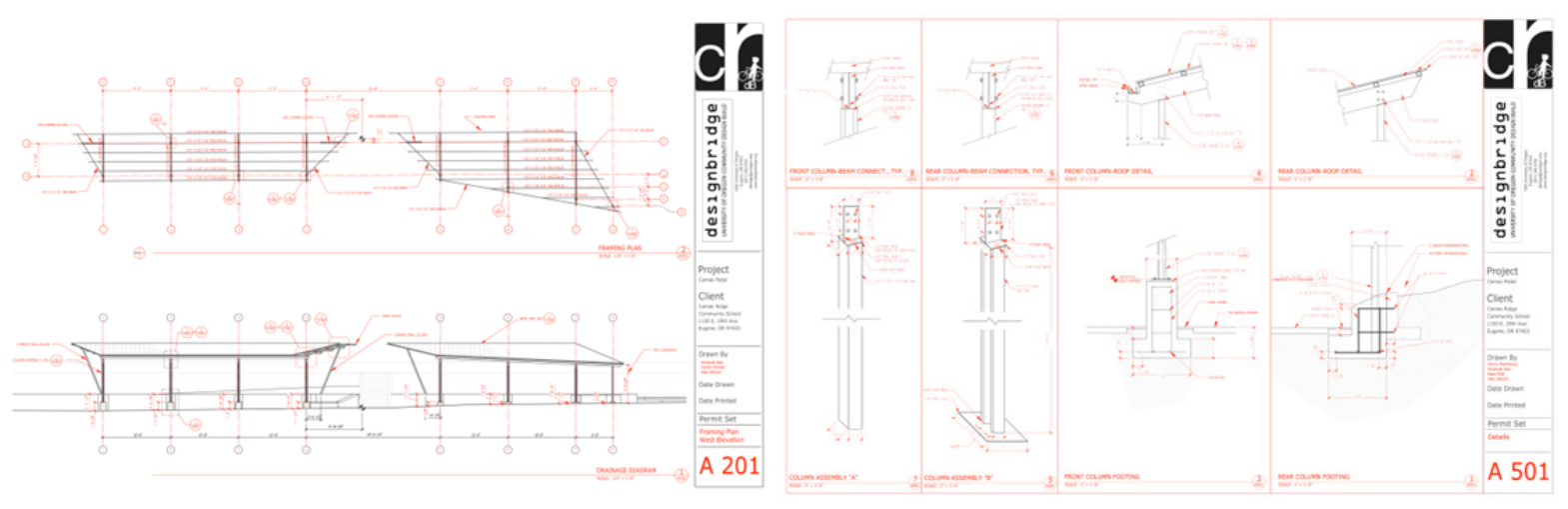

As winter term began, the client had not met the 50\% funding deadline. From a logistical, professional perspective it was time to reconsider the deliverables and approach. On the plus side, experience had demonstrated that designBridge projects could be a vehicle for material manufacturers and vendors to contribute in a focused way to their community. From an educational perspective, this approach necessitated a heightened knowledge of materials, properties, details and logistics on the part of the students, presenting a new set of professional exchanges and experiences.

None of this delayed the project schedule during this phase, and the winter quarter ended with a formal studio review of the design, a full-scale mockup, working drawings and $80 \%$ of material donations secured. 


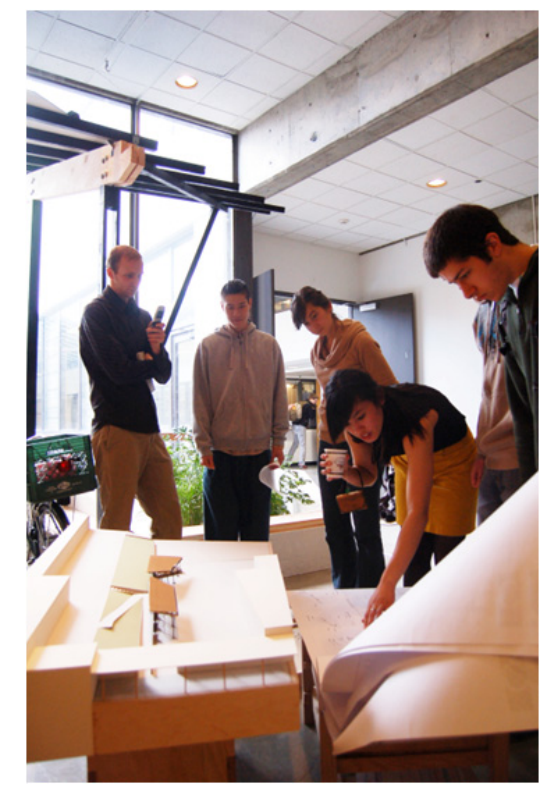

Camas Ridge Team: Alex Wilson, Nate Poel, Caitlin Gilman, Irene Callju, and Henry Malmberg talk to reviewers Shane Rhodes (SRTS), Jenny Young (UO Professor), Toby Barwood (PIVOT Architecture), John Rowell (UO Professor), and Juli Brode (Adjunct Instructor, designBridge Advisor).

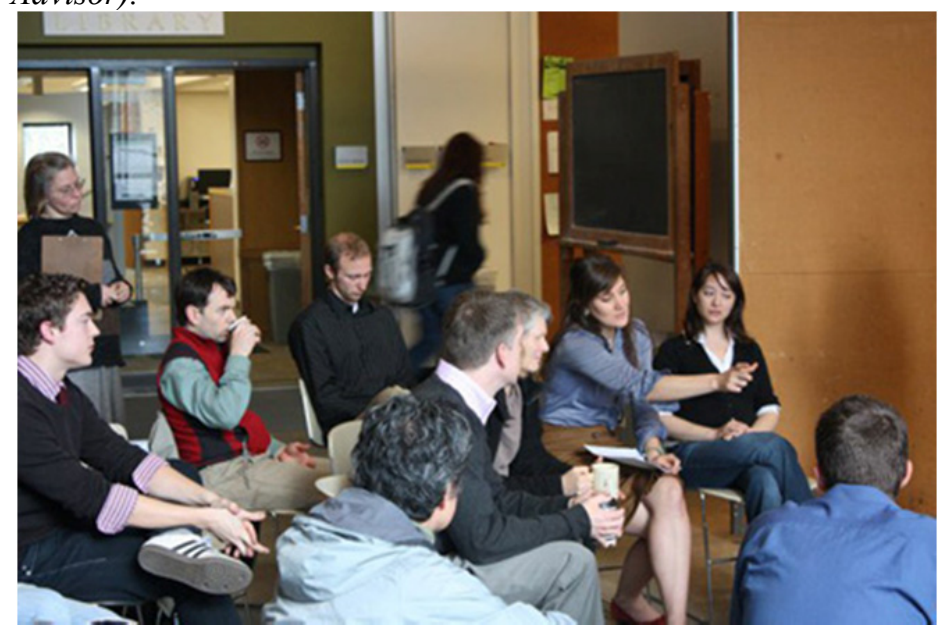

Spring 2010: designBridge Tech/Build (4)

Professor: John Rowell

This technical studies course was developed to support the material, detailing and assembly knowledge required for project construction. The course satisfies a degree requirement for advanced technology credits and is sufficiently popular to limit enrollment. Three graduate and six undergraduate Camas Ridge team members enrolled in the Tech/Build course, meeting twice a week for a total of four hours per week, and documenting a minimum of seven additional hours on the project outside of class time.

- A building permit was secured in March 2010, prior to the start of the spring quarter.

- One day each week, the instructor ran the class as a "construction meeting," where student teams presented progress of the past week, reviewed status of the schedule and budget, and trouble-shot construction challenges and details.

- Team members brainstormed about ways to enlist the schoolchildren in the building fabrication, and they enlisted a staff member/ceramicist to lead a tile workshop.
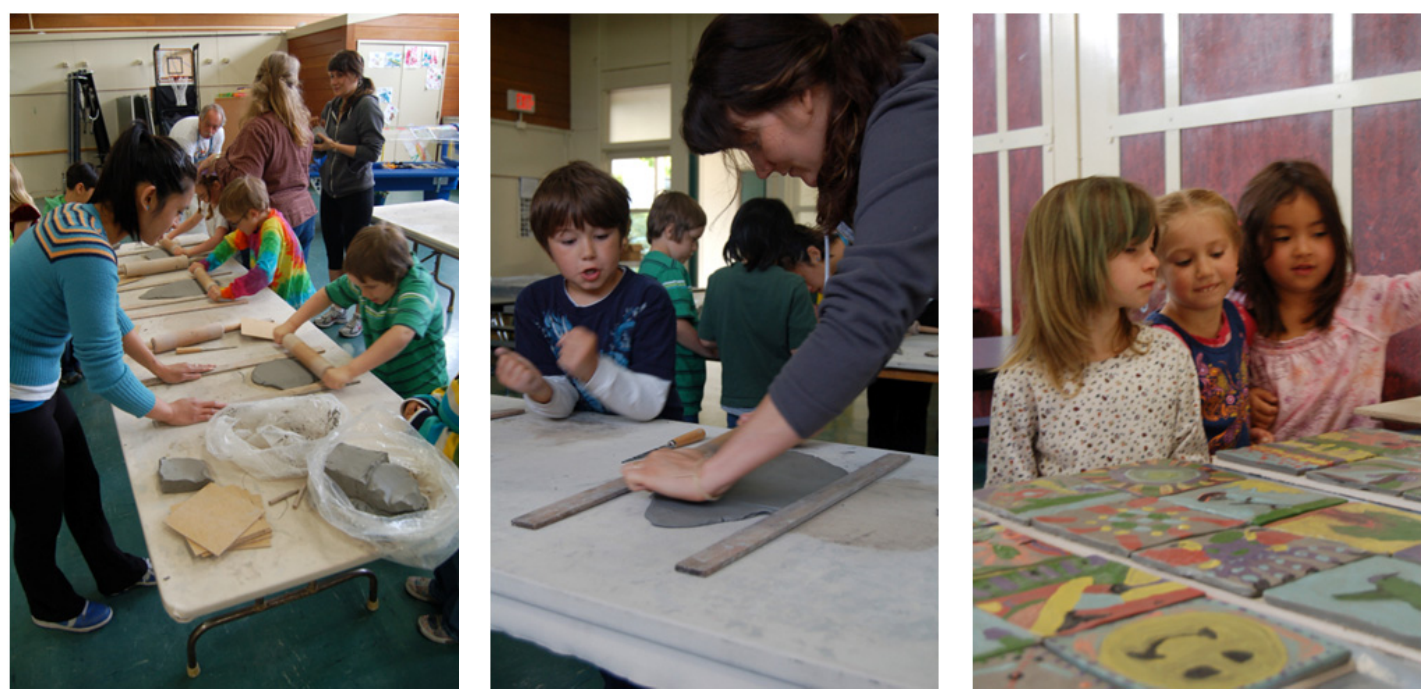

Amanda Asa and Caitlin Gilman assist Camas Ridge teachers and volunteers with a workshop where elementary students make and glaze tiles for their bike shelter - and the young artists are very pleased with their work! 
- Construction commenced with laying out the site for appropriate places for material storage, tools, a first aid station and waste. A surveyor volunteered services for accurate excavation and foundation measurements.

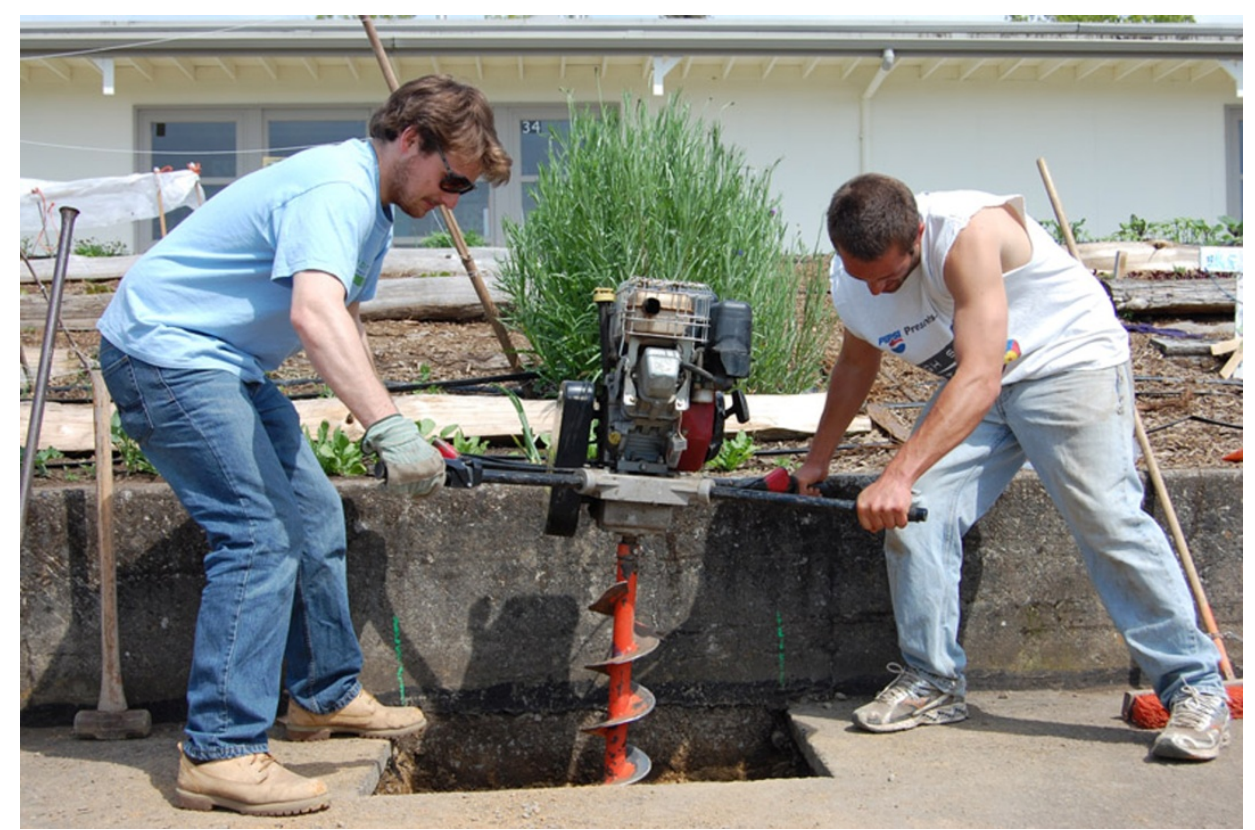

Following concrete sawing, Nick Venezia and Henry Malmberg excavate for footings.

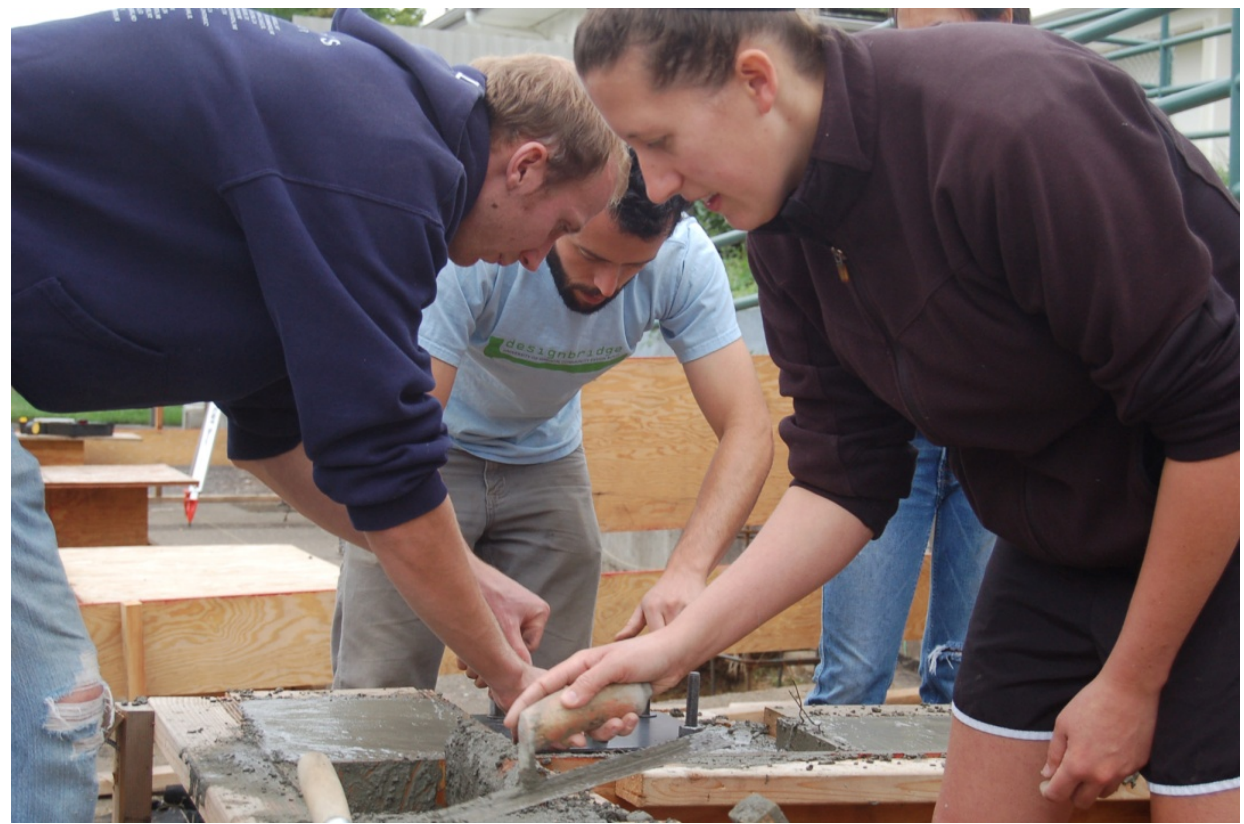

Troweling concrete to top of formwork at planter beds.

- This was the first time a designBridge project had utilized steel as a major construction material, and there was a great moment when students were perplexed by the formal RFIs (Requests for Information) they were getting from the steel company. They looked important! In the time span of about a week, students had drawn new details or refined dimensions in order to answer each RFI. They pinned them up in the Tech/Build class for review prior to sending them back to the 
contractor. The process demanded professional behavior and response; the experience and knowledge was one that could be shared with the entire Tech/Build class.

- The early part of the spring quarter yielded strong progress on preparing the site, but all was slowed due to two factors. The first was the time it took for students to properly respond to the RFIs from the steel company and make some additional calculations for their project. The second factor was that reliance on donations meant that designBridge was not in control of the procurement schedule.

Students arranged to be in Eugene for the early part of summer in order to receive and erect the steel, but the steel did not arrive before scheduling conflicts arose.

All community partners were informed and assured that construction would resume in early fall 2010 and designBridge requested an extension of the OTREC grant until December. The project did resume but was no longer supported by coursework, reducing the student building activities to regular weekend "Build Days."

\section{Grant and Project Completion}

The bike shelter was completed in late May 2011, and an early June final inspection meant it was operational for the remaining weeks of school. The ribbon cutting was a celebratory event: the elementary students presented personal cards, sang songs, and performed a play they had written about "their architects" and their bike shelter. One young man who loves bikes and riding them vowed that he was going to be an architect when he grew up - just so he could make bike shelters for people!

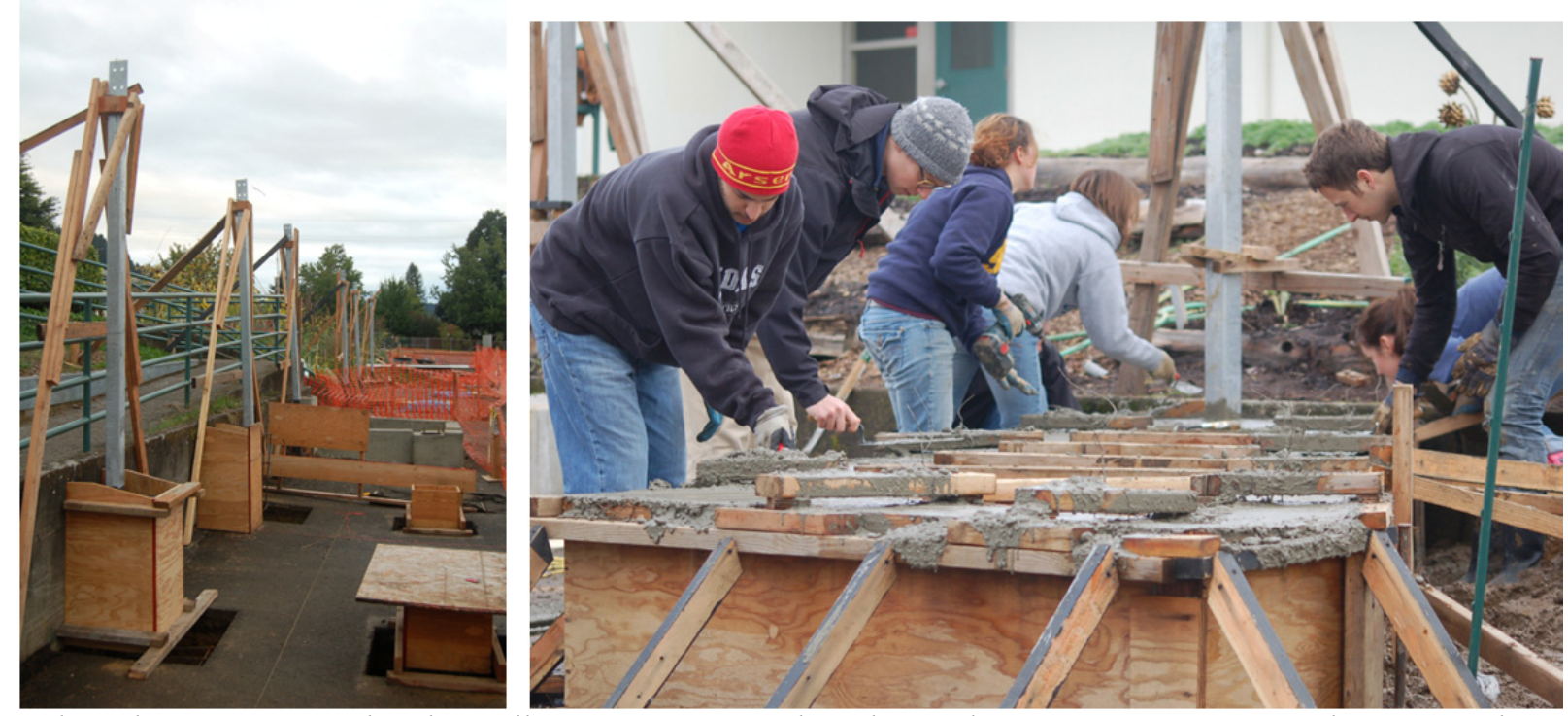

Column bracing assures that they will remain in proper place during the concrete pour. During the pour, students focus on sloping the tops of column bases for drainage and placing connectors for the front row of columns. 


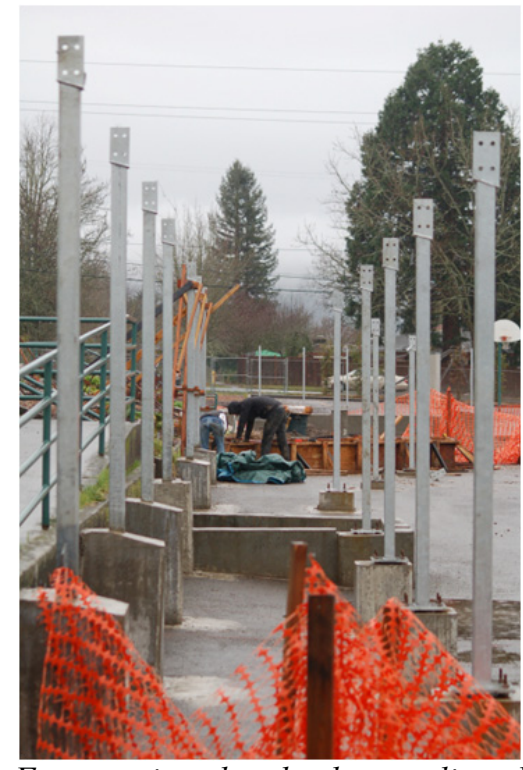

Forms stripped and columns aligned.

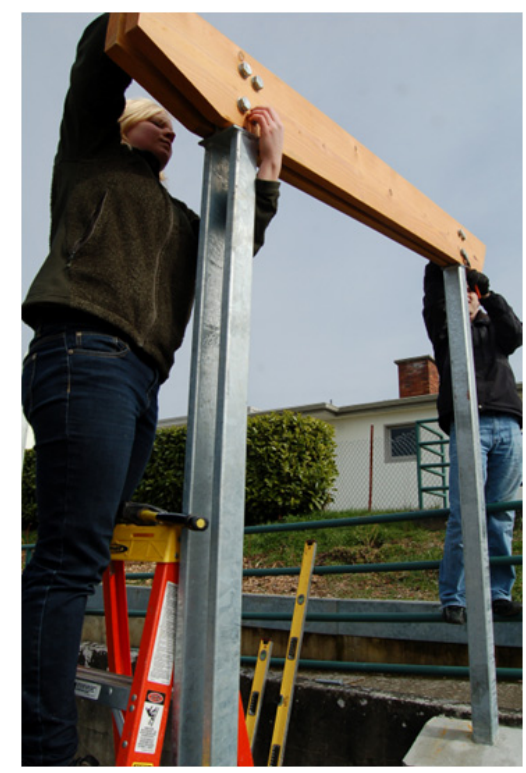

Fastening beams to columns.

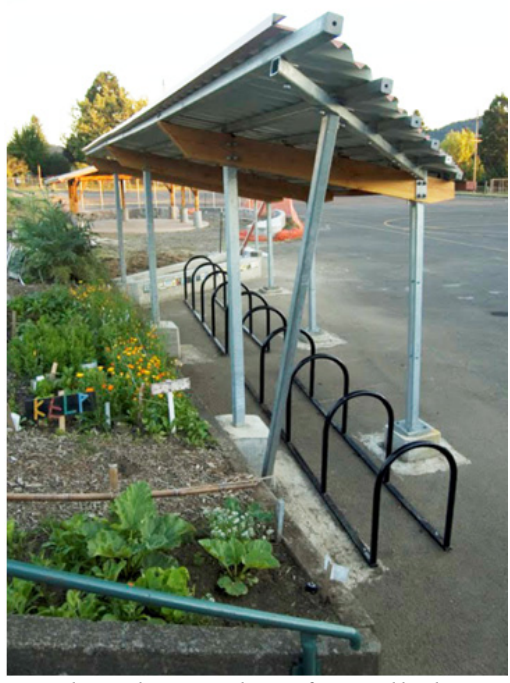

Steel purlins and roof installed.

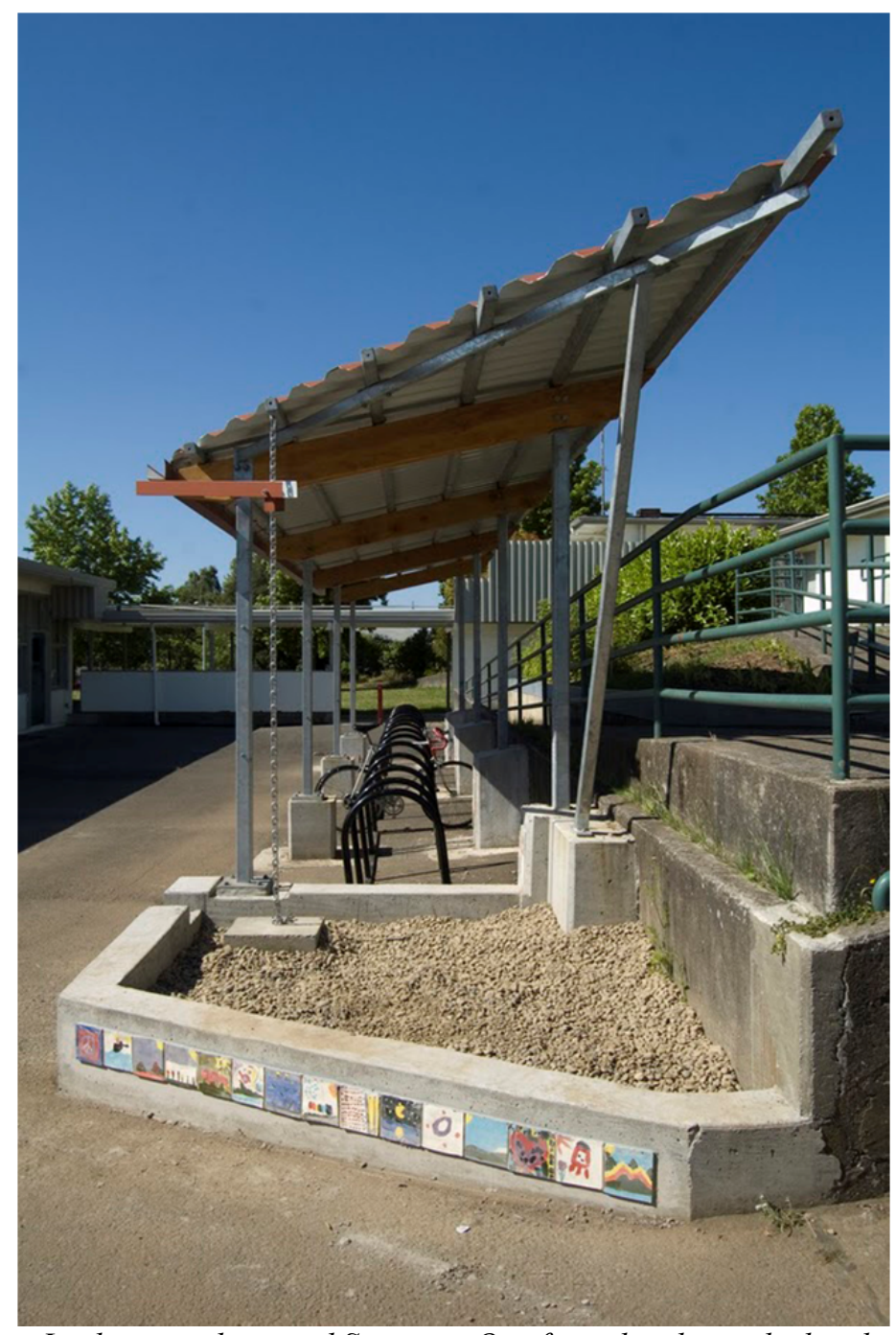

Looking north toward Structure One from the planter bed and stairs. 


\section{Activities and Presentations}

During the course of the year, designBridge attended and presented at several local events, and the student team presented to the client and public a number of times. designBridge leaders spoke at two community resource events, sharing work on Camas Ridge and raising awareness of the need for the development of integrated transportation solutions for the community.

- National Walk and Bike to School Day (October 7, 2009)

- Meet and greet with Camas Ridge parents, teachers and students (October 2009)

- Formal design charrette with students, parents and teachers (November 2009)

- An additional informal design activity and three meetings/presentations

- The 4th annual Eugene Walking and Biking Summit (January 23, 2010)

- Final design studio review/presentation (March 10, 2010)

- Tile making with Camas Ridge students (March 2010)

- National Walk and Bike to School Day (October 6, 2010)

- Ribbon-cutting ceremony (June 2011)

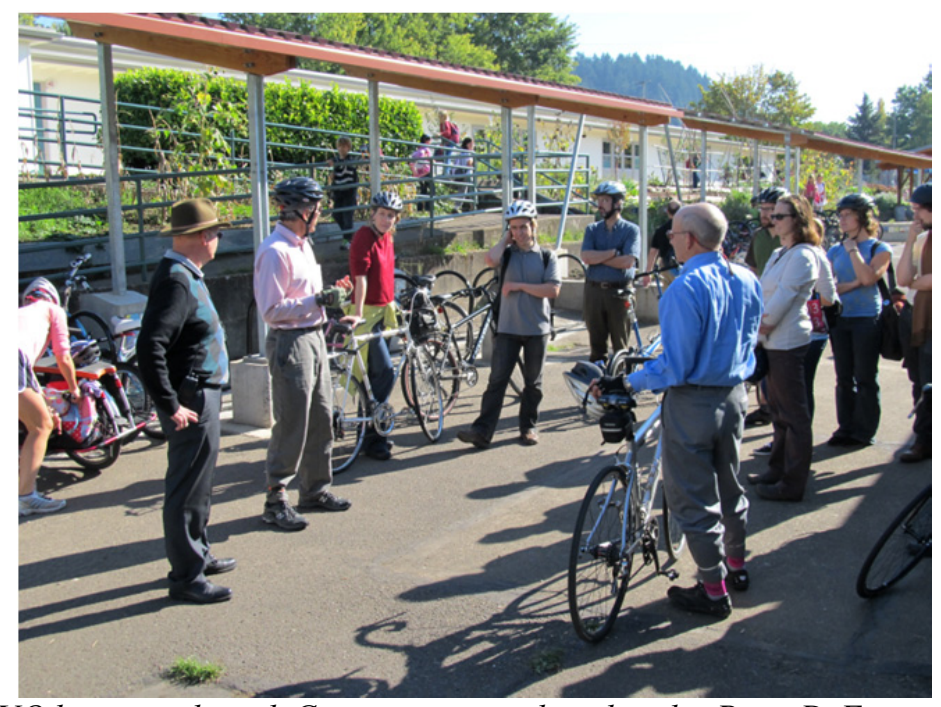

UO hosts a ride with Congressman and avid cycler Peter DeFazio, visiting a handful of newly implemented bicycle transportation projects.

Student Team and Resources

\begin{tabular}{|l|c|c|c|}
\hline Names & Pre-design (3) & Design Studio (6) & Build/Tech (4) \\
\hline $\begin{array}{l}\text { Nick Venezia } \\
\text { Project Manager }\end{array}$ & $\square$ & $\square$ & $\square$ \\
\hline $\begin{array}{l}\text { Nate Poel } \\
\text { Build Lead }\end{array}$ & & $\square$ & $\square$ \\
\hline Amanda Asa & $\square$ & $\square$ & $\square$ \\
\hline Henry Malmberg & $\square$ & $\square$ & $\square$ \\
\hline Alex Wilson & $\square$ & $\square$ & $\square$ \\
\hline Irene Callju & & $\square$ & $\square$ \\
\hline Caitlin Gilman & & $\square$ & $\square$ \\
\hline Kelsey McWilliams & $\square$ & $\square$ & $\square$ \\
\hline Sara Vernia & $278 \mathrm{hrs}$ & $720 \mathrm{hrs}$ & $694 \mathrm{hrs}$ \\
\hline Duy Vo & & & \\
\hline Hours Recorded Outside Class & & & $\square$ \\
\hline
\end{tabular}


Students keep timesheets for both the pre-design seminar and the technical building class, but they are not required to record their time outside of class during the design studio (department policy yields the figure above - 8 students X 10 hrs X 9 weeks, review and finals weeks excluded). An enthusiastic level of contribution was also made by many students not associated with coursework and academic credits, and we wish to acknowledge Katie Martin, Peter Hanley, Amelie Reynaud, Elizabeth Schmidt, Ted Shriro, Kent Wu, Sylvan Cambier (designBridge Student Director 09-10), and Shannon Arms (Student Director 10-11). The help of these students was invaluable as they were often cross-disciplinary, and their viewpoint, approach and expertise were complementary. This interaction also increases the student mentors' own skills, underscoring through explanation and articulation what they learned through their own experience and helping designBridge to become a stronger learning organization.

\section{Project Advisors}

Faculty Advisor: Juli Brode

Instructors for Associated Coursework: Juli Brode and John Rowell

Professional Mentor: Mark Young, Architect, Rowell Brokaw Architects

Professional Mentor: Toby Barwood, Architect, PIVOT Architecture

Professional Mentor: Adam Bonner, Site Supervisor, Hoffman Construction Co.

Visiting Instructor/Mule Project Workshop: Vic Liptak, Instructor, Woodbury University

\section{Client-Partners}

Wally Bryant, Principal, Camas Ridge Community School

Mike McCann, project applicant, initiator, parent, community member

Larry Massey, Architect, 4J School District

Dan Fuehring, Ben Brantley, 4J School District

Shane Rhodes, Program Manager, Eugene Safe Routes to School

\section{Community \& Professional Contributors}

Camas Ridge

Ming Surveying

Fortis Construction

Star Rental

W \& W Steel

Skyline Sheet Metal

Williams Fund, 2009-2010

Estimate of student hours at 1,692 X $\$ 14.70 / \mathrm{hr}$ has an associated value of $\$ 24,872.00$
4J School District

FarWest Steel

Knife River Precast Concrete

La Russo Concrete

Coping Trucking

RB Allen Construction

OTREC Grant, 2009 - 2010

\section{Documentation}

A degree of regular documentation is built into the designBridge process: Charrettes and community activities are captured on film and students are accustomed to documenting their progress in the design studio. If there is a challenge, it is in capturing the workflow of the building phase and the communication to a wider audience. The Camas Ridge team developed a blog in order to keep parents, $4 \mathrm{~J}$ members, donors and supporters apprised of progress and excited about the project. This gave the students an added imperative to photograph, document and post information. The project is also documented on the designBridge website: http://camaspedal.wordpress.com

http://designbridge.org

http://aaablogs.uoregon.edu/blog/201/11/09/rep-defazio-and-aa-students 


\subsection{PROJECT OUTCOMES}

The Camas Ridge bike-shelter project directly addresses a number of transportation-related topics and, by engaging various partners and placing students in a place of central responsibility and decision-making, the topics could be explored from multiple perspectives. The process fosters a rich and integrative learning environment. It yields a design solution uniquely appropriate to its site and users. It becomes a context in which the knowledge bases of both the university and community can be connected and utilized together. And it provides a basis upon which similar projects might be developed elsewhere.

The design team reviewed literature on health and statistics regarding decreased walking and biking of schoolchildren, both in the U.S. and abroad. Camas Ridge is an easy bike ride to UO and, when possible, the university students would bike together to meetings and work days, increasing their own understanding of the project site and setting an example for others. The designBridge team engaged elementary students directly through interviews and charrette activities in an effort to find out what was important to them, provocative and imaginative in their eyes. By including the elementary school students in the design process, most notably at the initial brainstorming phase and, later, in the fabrication of ceramic tiles for the shelter, there was an opportunity to raise general awareness and excitement about the coming shelter. Camas Ridge's principal and teachers utilized project-based curricula to incorporate multidisciplinary learning opportunities. They worked on physical education, science and environmental health, and safe ridership with their elementary pupils.

A group of four to six parents and kids attended meetings with designBridge students and Shane Rhodes (Eugene SRTS program manager), where they talked about current ridership, planned school routes and ridership goals. The existing bike rack technically accommodated 40 bikes, was often filled by kids' bikes on very nice days, but was seldom used by parents and teachers due to the damage caused to bikes. The determined goal was to exceed this if possible, but at the very least to match the existing accommodations, which already met the current building code requirements. The architects of the 4J School District and Shane had some clear ideas regarding school traffic and schoolyard access, but the desire to separate the shelter from the central transit "hub" also presented a challenge to the idea of a shelter that sought to symbolize the "hipness" and special accommodation for those who rode, skateboarded or walked. Meetings alone raised awareness of alternative transportation choices in the school community, and tabling at local cycling events presented opportunities to network with those outside the Camas Ridge neighborhood. These meetings promoted discussion and informed decision-making.

Two particularly visible examples of a confluence of these events can be found. One, the concept of incorporating kids' drawings into the investigative process became an art project where children made tiles so their ideas about transportation and health could be embodied and represented in the completed shelter. These were installed on the column bases. The second example is more complex, as a grant catalyzed a proposal for an environmental learning garden and outdoor meeting room, and its adjacency made for a new and unknown context just south of the proposed bike shelter. The design team did two things: First, they contacted the parent-architect to meet and share ideas about the two projects, although the outdoor room was in a nascent stage. Second, their own timetable being more advanced, they altered their proposal, attenuating the overall shape, breaking up the form and changing some planter beds/benches/steps in such a way as to "point to" what initially appeared to be a proposal for a simple, geometric, gazebo form. 


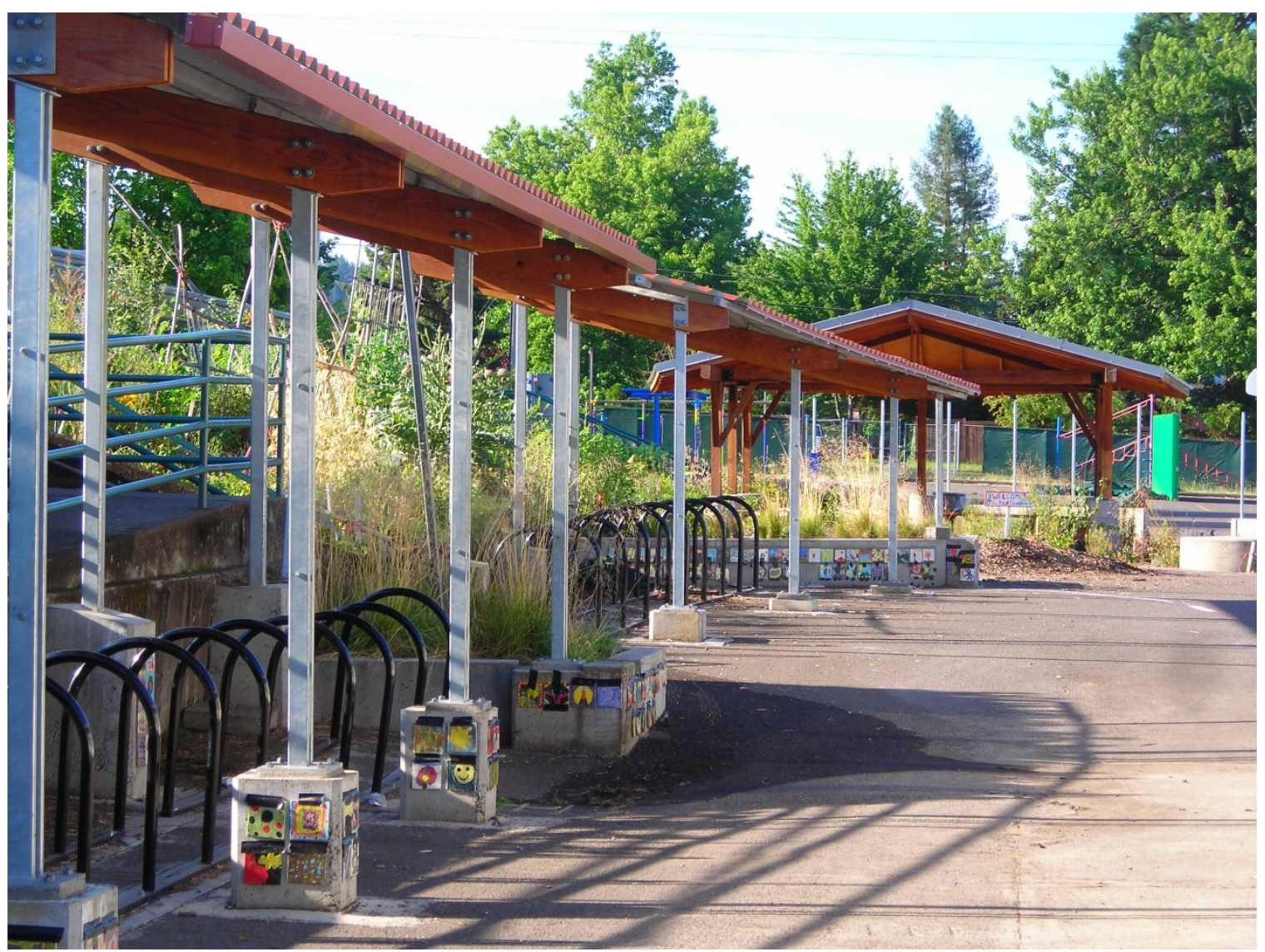

Photo of Camas Ridge Pedal, facing south toward the outdoor classroom. Hidden from view here, steps to the Learning Garden are located between two separate bike-shelter elements.

Focusing on the relationships and communications, both internal and external, shifts the emphasis of the workflow to one defined by community processes and relations, and represents a departure from a process that primarily focuses on managing the building as a physical product. Students learned that the nature of the profession is dynamic - design objectives can and do change during the course of the work. Individually, each designBridge student acquired a narrative understanding of the project, its requirements, and its processes. As a team, they gained an understanding of the strengths and weaknesses (resources) of the team, negotiated conflicting ideas, and formed common objectives. As they learned, in an entrepreneurial way, these management and planning skills, they were also becoming a more effective learning group.

The processes of the design phase evolved and the team changed accordingly. The project manager continued to keep the team focused on objectives and maintained nearly all internal and external communications, but the team decided that it was advisable for another person to coordinate all charrettes, presentations and blog entries. In addition, the team designated a third person to look at the project through the lens of "buildability," keeping the team on track in terms of engineering, materials and connections. The studio became a place of real seriousness and play - the weight of a tangible project was sometimes sobering and the obstacles frustrating, but the group had become more confident. Their decision to proceed in the face of a cost that was estimated at $\$ 25,000-\$ 30,000$ and actually funded by about $\$ 1,200$ and their own labor was both determined and inspired. They immediately contacted contractors and material vendors who might represent a source for all major building materials. Their interest in project funding increased considerably 
and the budget reflected new contacts, relationships and efforts. They succeeded in securing the needed donations, including the one for steel, the major component, and in securing letters committing to the donations, a condition of the 4J School District. The attention shifted back to structural calculations, final design reviews by UO faculty and guests, design refinement, and permit drawings. The permit drawings represented another challenge, as few school projects require resolution of design thinking and control at the level of material connection details and dimensions. There was a wonderful moment, after the review, when both professional mentors were having a friendly bicker about who would get the opportunity to correct and redline drawings for student to revise! The final set was submitted in late March and the school secured a building permit in early April.

Construction began as soon as site layout and excavation could take place. The Technical Building course was a synthesis of materials and methods learning (through the detail work and questions arising due to the projects themselves, and through field trips to manufacturing facilities and construction sites) and a weekly "construction meeting," as would take place in the field. Each student was responsible, at least once during the quarter, for leading the construction meeting and presenting the agenda and material for discussion. The appearance of a subcontractor's RFIs introduced an architect-to-contractor process heretofore unknown - an aspect of professional practice that can only be presented abstractly in the typical classroom. Here, it became a matter of general interest and understanding, as well as urgency, requiring a timely and professional response. The biggest logistical obstacle to the Camas Ridge project became the inability to manage the building schedule due to the dependence on the major material donations. The biggest gap in steady progress was in the wait for the structural steel components as they were delayed from late June - several students had remained in Eugene beyond the school in order to receive and erect the steel - to late July. The consequence was a largely disbanded team and regular work did not commence until the following September, by which time the project was no longer supported by coursework. The students remained committed; several were in their final, demanding year of studies, but the project progressed steadily, albeit primarily on weekends.

The design and development of this project satisfied the seemingly mundane need for a bike shelter. The community education and conscious engagement increased awareness of the need for safe and easy bike travel throughout Eugene. Connecting directly with children during the design process promoted a change in their travel behavior and offered an incentive and amenity to do so. A number of elementary school children at Camas Ridge are excited at the idea of the architecture and planning professions - they are convinced that they can bike and make bike roads, build bike shelters and design bike cities.

The university students benefited from an effective learning experience, one that involved a degree of critical reflection and an understanding of the value of their own experience. The opportunities to connect technology and theory to practice are high, and those opportunities can be fully leveraged when the process is active, engaged and collaborative and when the mentoring is timely (one reason these learning pedagogies are mentor-intensive).

Another way to increase this reflective learning component is to place high value on students mentoring and teaching fellow students. In the course of the bike-shelter project, there was an effort to consult and include students who had worked on the previous shelter project (Roosevelt Middle School, 2009) and the OTREC funding made it possible for one of the Roosevelt project managers to become the graduate teaching fellow for the Tech/Build class in 2010. The other became the designBridge organization's student director and supported the project in other ways, 
assisting in presentations; advising and referring contractors; and soliciting support for build days. One aspect of this peer-to-peer learning was that the students who participated in this project were more aware of what they were learning while they were learning it and, as a result, they increased their tacit knowledge. That knowledge "...is not typically reportable since it is deeply rooted in action and involvement in a specific context." (Raelin, 2008). Consequently, students became more skillful, less intimidated by what they do not know, and more confident in their ability to continue to learn. Many of the team became interested in community work and civic processes, and students have developed teamwork and communication skills that will play a large role in their professions. 


\subsection{REFERENCES}

Ash, S. and P. Clayton. 2009. Generating, Deepening, and Documenting Learning: The Power of Critical Reflection in Applied Learning. Journal of Applied Learning in Higher Education Vol. 1: $25-48$.

Centers for Disease Control and Prevention. Childhood Obesity Facts.

http://www.cdc.gov/obesity/data/childhood.html

Centers for Disease Control and Prevention. Fact Sheet: Obesity Among Low-Income Pre-School Children. http://www.cdc.gov/obesity/data/childhood.html

Centers for Disease Control. Strategies and Solutions. http://www.cdc.gov/obesity/childhood/solutions.html

City of Eugene. 2008. Pedestrian and Bicycle Strategic Plan. Note: Eugene has yet to finalize policy of the Eugene Pedestrian and Bicycle Master Plan (last report Nov 2011).

Healthy Children Organization. 2012. Emphasis on Exercise. http://www.healthychildren.org/English/health-issues/conditions/obesity/pages/Emphasis-on-Exe $\underline{\text { rcise.aspx }}$

Killingsworth, R. and J. Lamming. 2001. Development and public health: Could our development patterns be affecting our personal health? Urban Land, Vol. 60, No. 7: 12, 14-17.

Krebs, N. and M. Jacobsen. 20073. Prevention of Pediatric Overweight and Obesity, Pediatrics Vol. 112 No. 2: 424 -430. Policy reaffirmed and republished, Pediatrics, Vol. 119, 2007.

Loukaitou-Sideris, A. 2005. Does the Built Environment Influence Physical Activity? Examining the Evidence. TR News, Mar/Apr, re-published as TRB Special Report 282.

National Architecture Accrediting Board. 2008. Position Paper for the NAAB 2008 Accreditation Review Conference. http://app.ncarb.org/forms/ARCpositionpaper.pdf

National Center for Safe Routes to School. Getting Results: SRTS Programs That Increase Walking and Biking to School. srts_gettingresults_walkbike.pdf

Ogden, C., M. Carroll, B. Kit and K. Flegal. 2010. Prevalence of Obesity Among Children and Adolescents: United States, 2009 - 2010. Data from the National Health and Nutrition Examination Surveys, http://www.cdc.gov/nchs/data/databriefs/db82.htm

Raelin, J. 2008.Work-Based Learning, Bridging Knowledge and Action in the Workplace. San Francisco: Jossey-Bass.

Safe Routes to School. Program Resources. http://www.saferoutesinfo.org/program-tools/search-resources 
U.S. Census Bureau, 2000, figures for Lane County, Oregon, http://factfinder2.census.gov/faces/tableservices/jsf/pages/productview.xhtml?src=bkmk

U.S. Department of Health and Human Services, Office of Disease Prevention and Health Promotion.(2008). 2008 Physical Activity Guidelines for Americans. Retrieved from: http://www.health.gov/paguidelines/guidelines/default.aspx

U.S. Environmental Protection Agency, Greenhouse Gas missions, http://www.epa.gov/climatechange/ghgemissions/gases/co2.html\#Trends 



\section{GOTREC \\ AND EDUCATION CONSORTIUM}

P.O. Box 751

Portland, OR 97207

OTREC is dedicated to stimulating and conducting collaborative multi-disciplinary research on multi-modal surface transportation issues, educating a diverse array of current practitioners and future leaders in the transportation field, and encouraging implementation of relevant research results. 